\title{
PROFESIONALISME GURU DALAM PANDANGAN QS. AI-ISRA': 84
}

\author{
M. Saiyid Mahadhir \\ Sekolah Tinggi Ilmu Tarbiyah Raudhatul Ulum Sakatiga \\ Email: saiyid.mahadhir@gmail.com
}

\begin{abstract}
Abstrak
Didalam Al-Quran proses pendidikan sering diungkap dengan tiga istilah: (1) tarbiyah, (2) ta'lim dan (3) ta'dib. Murobbi adalah orang yang melakukan aktivitas menumbuh kembangkan peserta didik (fisik, akal dan jiwa), memperbaikinya, menuntunnya, menjaga dah memeliharamya. Mu'allim adalah orang yang menguasai ilmu dan mampu mengembangkannya serta menjelaskan fungsinya dalam kehidupan, menjelaskan dimensi teoritis dan praktisnya, sekaligus melakukan transfer ilmu pengetahuan, internalisasai, serta implementasinya. Mu'addib adalah orang yang mampu mengajarkan adab serta mampu menyiapkan peserta didik untuk bertanggung jawab dalam membangun peradaban yang berkualitas di masa kini maupun masa yang akan datang. Profrsionalisme berarti bersifat profesional, merupakan paham yang mengajarkan bahwa setiap pekerjaan harus dilakukan oleh orang yang profesional. Orang yang profesional adalah orang yang memiliki profesi. Dalam Islam, setiap pekerjaan harus dilakukan secara profesional, dalam arti harus dilakukan secara benar. Hal ini hanya mungkin dilakukan oleh orang yang ahlinya. Apapun jenis profesi yang disandang, hendaknya dilakukan dengan profesional. Profesionalisme guru dalam alQuran surat Al-Isra': 84 sesungguhnya diambilkan dari adanya pendapat mufasir yang memberikan penekanan terhadap makna kata 'ala syakilatihi yang berarti bentuk, tabiat, jalan, tujuan, niat, agama, kebiasaan, akhlak dan madzhab. Dari sinilah yang dapat ditarik pemahaman bahwa ayat tersebut memberikan isyarat pekerjaan itu harus dilakukan secara profesional. Demikian pula dengan profesi guru harus dilakukan secara profesional.
\end{abstract}

Kata Kunci: Profesionalisme, Guru, Al-Qur'an

\section{Pendahuluan}

Dalam proses pembelajaran setidaknaya ada tiga komponen pokok yang harus ada: (1) yang memberi pelajaran (guru), (2) yang menerima pelajaran (murid) dan (3) bahan pelajaan yang diajarkan. Seorang guru tidak hanya terbatas pada melakukan transfer ilmu, tetapi lebih dari itu yaitu: mendidik, yang lebih bersifat menanamkan nilai-nilai pada anak didik di luar ilmu pengetahuan yang bersifat bebas itu ${ }^{1}$. Dilain tempat Muhadjir mengatakan bahwa aktifitas pendidikan, bukan sekedar mengalihkan informasi atau pengetahuan, melainkan memberikan pengetahuan sekaligus implikasi nilai (baik buruk), dan juga dengan menggunakan cara/jalan yang normatif baik. Hal ini menunjukkan bahwa ada upaya

1Syafei,I. Konsep Guru Menurut Al-Ghazali, Pendekatan Filosofis Pedagogis, Yogyakarta: Duta Pustaka, 1992, hal. 27 


\section{Profesionalisme Guru dalam Pandangan QS. Al-Isra' : 84 M. Saiyid Mahadhir}

terprogram dari para pendidik yang menjiwai, guna membantu subyek didik agar dapat berkembang ke tingkat normatif yang lebih baik ${ }^{2}$.

Didalam Al-Quran proses pendidikan sering diungkap dengan tiga istilah: (1) tarbiyah, (2) ta'lim dan (3) ta'dib. Ahmad Tafsir menjelaskan bahwa pendidikan merupakan arti dari kata tarbiyah. Kata tersebut berasal dari tiga kata yaitu; rabba-yarbu yang berarti bertambah atau tumbuh, dan rabiya-yarbaa yang berarti menjadi besar, serta rabba-yarubbu yang berarti memperbaiki, menguasai urusan, menuntun, menjaga, memelihara ${ }^{3}$.

Ta'limmerupakan bentuk masdar dari kata 'allama yang diambil dai kata dasarnya 'alima yang berarti mengetahui. Kata tersebut menunjukkan proses transformasi ilmu yang rutin dan terus menerus sehingga memberi pengaruh pada muta'allim (pelajar).

Sedangkan istilah ta'dib merupakan bentuk masdar kata addaba yang berarti mendidik atau memberi adab, dan ada yang memahami arti kata tersebut sebagai proses atau cara Tuhan mengajari para Nabi-nya. Naquib al-Attas mengatakan bahwa adab telah banyak terlihat dalam sunnah nabi, dan secara konseptual menyatu bersama ilmu dan amal. Karenanya, istilah ta'dib dalam pendidikan Islam digunakan untuk menjelaskan proses penanaman adab kepada manusia ${ }^{4}$.

Demikian tergambar tugas besar bagi seorang guru yang tidak hanya sebatas transfer pengetahuan saja. Oleh karena itu profesionalisme guru dalam melakukan proses mendidik anak pada lembaga pendidikan Islam atau pendidikan secara umum, menjadi penting untuk diwujudkan dalam dunia pendidikan. Berdasarkan hal di atas, sehingga artikel ditulis dalam rangka melakukan kajian terhadap profesionalisme guru dalam perspektif pendidikan Islam.

\section{Profesionalisme Guru}

Jika tarbiyah, ta'lim dan ta'dib adalah sebuah proses mendidik maka orang yang melakukan tugas itu disebut dengan murabbi, mu'allim dan muaddib, maka:

1. Murobbi adalah orang yang melakukan aktivitas menumbuh kembangkan peserta didik (fisik, akal dan jiwa), memperbaikinya, menuntunnya, menjaga dah memeliharamya.

2. Mu'allim adalah orang yang menguasai ilmu dan mampu mengembangkannya serta menjelaskan fungsinya dalam kehidupan, menjelaskan dimensi teoritis dan praktisnya, sekaligus melakukan transfer ilmu pengetahuan, internalisasai, serta implementasinya.

3. Mu'addib adalah orang yang mampu mengajarkan adab serta mampu menyiapkan peserta didik untuk bertanggung jawab dalam membangun peradaban yang berkualitas di masa kini maupun masa yang akan datang.

Berdasarkan beberapa pengertian diatas, maka guru dalam Islam dapat dimaknai sebagai orang-orang yang bertanggung jawab terhadap perkembangan anak didik yang bertugas untuk mendidik dengan mengupayakan perkembangan seluruh potensi peserta didik, baik potensi fisik, akal maupun jiwa.

Kata profesi itu sendiri secara bahasa mempunyai arti pandai, cakap, piawai. Namun profesi juga dapat berarti riwayat pekerjaan, pekerjaan tetap, mata pencarian, dan pekerjaan yang merupakan sumber kehidupan. ${ }^{5}$ Sehingga tidak salah jika selama ini makna profesi

${ }^{2}$ Muhadjir, N. Ilmu Pendidikan dan Perubahan Sosial: Teori Pendidikan Pelaku Sosial Kreatif, Yogyakarta: Rake Sarasin, 2000, hal. 10

${ }^{3}$ Ahmad Tafsir, Ilmu Pendidikan dalam Perspektif Pendidikan Islam, (Cet. VII; Bandung PT. Remaja Rosdakarya, 2003), h. 45

4 Naquib al-Attas, Konsep Pendidikan dalam Islam: Suatu Rangka Pikir Pembinaan Filsafat Pendidikan Islam, (Bandung: Mizan, 1997), h. 62-91

5 Partanto, P. A. Kamus ilmiah populer, Surabaya: Arkola, 1994, hal. 627 
Volume 3 Nomor 2 Edisi Desember 2018

P-ISSN : 2541-3686

lebih dikenal dengan pekerjaan, berupa kebiasaan yang dilakukan seseorang sehingga ia dapat hidup dari hasil keringatnya ${ }^{6}$.

Dalam Kamus Besar bahasa Indonesia, kata profesional berarti bersangkutan dengan profesi, memerlukan kepandaian khusus untuk menjalankannya, dan mengharuskan adanya pembayaran (upah atau gaji) untuk melakukanya (sebagai lawan dari amatir) ${ }^{7}$. Berdasarkan definisi ini profesional itu ternnyata berkaitan dengan kinerja yang dilakukan, itu artinya orang tersebut didalam bekerja mempunyai ilmu dan kemampuan serta menguasai cara-cara khusus dalam melakukan pekerjaannya, sehingga mempunyai kemudahan-kemudahan dan hasilnya memuaskan, lawan dari itu semua disebut dengan amatir.

Sedangkan profrsionalisme berarti bersifat profesional. Dalam kamus bahasa Indonesia profesionalisme diartikan sebagai mutu, kualitas dan tindak tanduk yang merupakan ciri suatu profesi $^{8}$.

\section{Profesionalisme Dalam Pandangan QS. Al-Isra':}

Surat Al-Isra' adalah surat makkiyyah, kecuali ada beberapa ayat saja dalam surat ini yang dinilia sebagai ayat madaniyyah, jumlah ayatnya adalah 111 ayat, diturunkan setelah surat Al-Qashash, demikian informasi dari Az-Zamakhsyari dalam tafsir $\mathrm{Al}$ Kasysyaf. ${ }^{9}$ Dinamakan dengan Al-Isra' yang berarti memperjalankan di malam hari, berhubung peristiwa Isra' Nabi Muhammad saw dari Masjidil Haram di Mekah ke Masjidil Aqsha di Baitul Maqdis dicantumkan pada ayat pertama dalam surat ini. Surat ini dinamakan pula dengan Bani Israil artinya keturunan Israil berhubung dengan permulaan surat ini, yakni pada ayat kedua sampai dengan ayat kedelapan dan kemudian dekat akhir surat yakni pada ayat 101 sampai dengan ayat 104, Allah menyebutkan tentang Bani Israil yang setelah menjadi bangsa yang kuat lagi besar lalu menjadi bangsa yang terhina karena menyimpang dari ajaran Allah swt.

Seacara umum isi pokok surat ini adalah:

1. Keimanan. Allah tidak mempunyai anak baik berupa manusia ataupun malaikat; Allah pasti memberi rezki kepada manusia; Allah mempunyai nama-nama yang paling baik; Al Quran adalah wahyu dan Allah yang memberikan petunjuk, penawar dan rahmat bagi orang-orang yang beriman; adanya padang Mahsyar dan hari berbangkit.

2. Hukum-hukum. Larangan-larangan Allah tentang: menghilangkan jiwa manusia; berzina, mempergunakan harta anak yatim kecuali dengan cara yang dibenarkan agama; ikut-ikutan baik dengan kata-kata maupun dengan perbuatan dan durhaka kepada ibu bapa. Perintah Allah tentang: memenuhi janji dan menyempurnakan timbangan dan takaran, melakukan shalat lima waktu dalam waktunya.

3. Kisah-kisah. Kisah Isra' Nabi Muhammad saw, juga beberapa kisah tentang Bani Israil.

4. Dan lain-lain. Pertanggungan jawab manusia masing-masing terhadap amal perbuatannya; beberapa faktor yang menyebabkan kebangunan dan kehancuran suatu umat; petunjuk-petunjuk tentang pergaulan dengan orang tua, tetangga dan masyarakat; manusia makhluk Allah swt yang mulia, dalam pada itu manusia mempunyai pula sifatsifat yang tidak baik seperti suka ingkar, putus asa dan terburu-buru; dan persoalan roh. Selanjutnya untuk membahas tentang profesionalisme guru dalam surat ini penulis mencoba menggunakan ayat 84 dari surat ini:

${ }^{6}$ Purwanto, Y. Etika Profesi: Psikologi Profetik Perspektif Psikologi Islami, Bandung: Refika Aditama, 2007, hal. 1

7Depdikbud, Kamus Besar Bahasa Indonesia, Jakarta: Balai Pustaka, 2005, hal. 897

${ }^{8}$ Depdikbud, Kamus Besar Bahasa Indonesia, Jakarta: Balai Pustaka, 2005, hal. 897

${ }_{9}^{9}$ Az-Zamakhsyari, Al-Kasysyaf, Beirut, Dar Al-Kitab Al-Arabi, 1407 H, jilid 2, hal. 646 


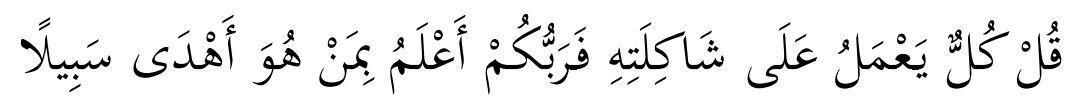

Katakanlah: Tiap-tiap orang berbuat menurut keadaannya masing-masing. Maka

Tuhanmu lebih mengetahui siapa yang lebih benar jalannya (QS. Al-Isra': 84)

Kata kunci dari ayat diatas yang kami gunakan untuk menunjukkan makna

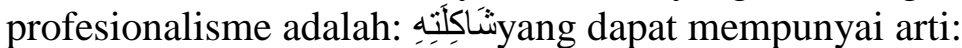

1. Bentuk, tabiat ${ }^{10}$

2. Jalan, tujuan ${ }^{11}$

3. Niat $^{12}$

4. Agama $^{13}$

5. Kebiasaan $^{14}$

6. Akhlak $^{15}$

7. Madzhab ${ }^{16}$

Para ulama tafsir memberikan penjelasan terkait ayat ini:

1. Tafsir Ibnu Katsir ${ }^{17}$

Ayat ini mengandung makna ancaman terhadap orang-orang musyrik dan peringatan bagi mereka, terhadap keyakinan dan sifat mereka yang selalu mendustakan Allah swt terhadap segala kenikmatan yang diperole, perihalnya sama dengan apa yang disebutkan Allah Swt. dalam ayat lain, yaitu:

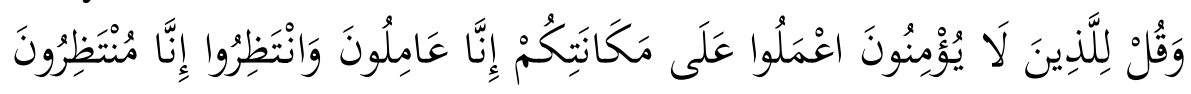

dan Katakanlah kepada orang-orang yang tidak beriman: "Berbuatlah menurut kemampuanmu; Sesungguhnya Kami-pun berbuat (pula)."(QS.Hud: 121)

Karena itulah dalam ayat ini disebutkan oleh firman-Nya:

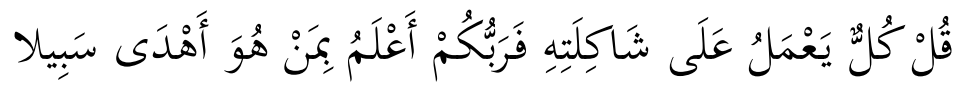

Katakanlah: "Tiap-tiap orang berbuat menurut keadaannya masing-masing" Maka Tuhan kalian lebih mengetahui siapa yang lebih benar jalannya. (Al-Isra: 84)

\section{Tafsir Al-Maraghi}

Terhadap nikmat Allah swt maka baik yang bersyukur atau yang kufur keduanya berjalan sesuai sesuai dengan jalannya dan tabiat keadaanya apakah dia memang pada dasarnya berada dijalan kebaikan atau berada dijalan keburukan. Untuk itu maka Allah swt lebih tahu dari siapapun juga tentang siapa diantara kamu yang lebih nyata jalannya terhadap kebenaran dan dia berikan kepada orang tersebut pahala yang sempurna. Allah swt juga maha

${ }^{10}$ Ibnu Qutaibah, Gharib Al-Quran,

11 At-Thabari, Jami' Al-Bayan fi Ta'wil Al-Quran, Muassasah Ar-Risalah, 2000, jilid 17, hal. 540-

12 At-Thabari, Jami' Al-Bayan..., jilid 17, hal. 541

13 At-Tahabari, Jami' Al-Bayan..., jilid 17, hal. 542

${ }_{14}$ Al-Mawardi, An-Nukat wa Al-Uyun, Beirut, Dar Al-Kutub Al-Ilmiyyah, t.t, jilid 3, hal. 269

${ }^{15}$ Al-Mawardi, An-Nukat..., jilid 3, hal. 269

16 Az-Zamakhsyari, Al-Kasysyaf..., jilid 2, hal. 690

17 Ibnu Katsir, Al-Quran Al-Azhim, Dar Tahibah, 1999, jilid 5, hal. 113 
Volume 3 Nomor 2 Edisi Desember 2018

P-ISSN : 2541-3686

tahu siapakah diantara kamu yang lebih sesat jalannya, lalu Dia menghukumnya sesuai dengan yang patut diterima karena memang tabiat aslinya dan bakat yang mereka peroleh. ${ }^{18}$

\section{Tafsir Fi Zhilal Al-Quran ${ }^{19}$}

Kenikmatan itu pada tabiatnya menyesatkan dan menyombongkan selama manusianya tidak mengingat sang Pemberi nikmat itu sehingga ia bersyukur. Sedangkan kesengsaraan pada tabiatnya membuat manusia putus asa dan pesimis selama manusia tidak tersambung kepada Allah. Dari sini akan tampak nilai keimanan dan apa yang terkandung didalamnya berupa rahmat baik dalam keadaan senang atau susah.

Lalu kemdian Allah swt menegaskan bahwa setiap manusia dan setiap kelompok (organisasi) akan bekerja sesuai dengan jalan dan tujuannya masing-masing, sedangkan apa yang dikerjakan berikut jalan dan tujuan dari pekerjaan itu akan menjadi penilaian Allah swt, maka berhati-hatilah dalam megambil jalan dan tujuan, pastikan bahwa tujuan dan jalan yang ditempuh jalan yang penuh petunjuk dan jalan yang akan menuju Allah swt.

\section{Tafsir Marah Labid}

Syeikh Nawawi al-Bantani menguraikan bahwa:Kata 'ala syakilatihi diartikan dengan: cara atau jalan yang sesuai dengan keadaannya dalam memperoleh petunjuk Allah dan menghindari kesesatan. Sehingga bila seseorang mempunyai jiwa yang bersih maka akan memunculkan perbuatan yang baik dan jika seseorang mempunyai jiwa yang kotor maka akan melahirkan perbuatan yang jelek pula. ${ }^{20}$

\section{Tafsir Al-Mishbah}

Berdasarkan keterangan yang dikemukakan oleh mufassir diatas, menurut penulis penjelasan itu memberikan isyarat bahwa bekerja berdasarkan keadaannya, jalannya, tujuannya, niatnya, dst, terkandung makna bahwa seseorang itu berbuat atas dasar karakter dan tabiat aslinya, itu artinya kemampuan seseorang dalam melakukan pekerjaan itu memang sudah ada dalam jiwanya, dan tentulah ketika ia bekerja ada panggilan jiwa untuk melakukan pekerjaan tersebut. Dengan demikian kerja yang dilakukan itu berada dalam koridor profesionalisme. Dan ayat ini sepertinya memberikan isyarat pula tentang pekerjaan haruslah dilakukan dengan profesional.

Sehingga ayat yang telah dikemukakan diatas, penulis mengambil pemahaman dengan menggunakan kaedah yang berbunyi:

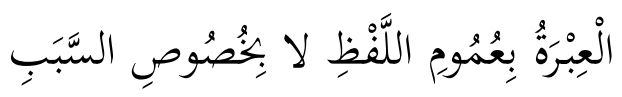

Ibrah itu diambil dengan menggunakan umumnya lafadz dan bukan khususnya sebab ${ }^{21}$

Walaupun ayat ini secara redaksi berbicara tentang manusia yang kufur terhadap nikmat Allah, dan perilaku atau perbuatan kufurnya itu atas dasar memang itu sudah menjadi tabiatnya, jalannya, niatnya dan kebiasannya, itu juga berarti bahwa perbuatan kufur itu memang dilakukan atas dasar kesadarannya, kekufurannya itu seakan sudah menjadi penggilan jiwanya, bekerja itu adalah profesi dan panggilan jiwa itu adalah profesionalisme. Bekerja sesuai dengan kemampuannya tanpa adanya pemaksaan dan tanpa dipaksakan itu juga profesonalisme.

\footnotetext{
${ }^{18}$ Al-Maraghi, Tafsir Al-Maraghi, Mesir: Al-Babi Al- Halabi, 1946, jilid 15, hal. 87

${ }^{19}$ Sayyid Quthb, Fi Zhilal Al-Quran, Beirut, Dar As-Syuruq, 1412 H, jilid 4, hal. 2249

${ }^{20}$ Nawawi Al-Bantani. Marah Labid, Beirut: Dar Al-Kutub Al-Imiyyah, 1417 H, jilid 1, ha. 635

${ }^{21}$ As-Suyuthi, Al-Itqan fi Ulum Al-Quran, Mesir, Al-Haiah Al-Mishriyyah, 1974, jilid 1, hal. 110
} 


\section{Profesionalisme Guru dalam Pandangan QS. Al-Isra' : 84 M. Saiyid Mahadhir}

Akan tetapi dapat juga dipahami bahwa ayat tersebut berlaku umum hingga. Karena sifat-sifat profesional seperti kemampuan, kesadaran, sesuai dengan katakter yang menjadi esensi pada ayat tersebut tidak hanya untuk untuk mereka yang diceritakan secara langsung dalam ayat tersebut, maka penulis mengambil kesimpulan bahwaayat diatas memberikan penjelasan kepada manusia bahwa didalam melakukan pekerjaan, kegiatan atau usaha apa saja hendaknya sesuai dengan profesionalismenya.

Guru dalam ini juga harus memiliki kemampuan-kemampuan dasar sebagai kompetensi yang dapat mengarahkan dirinya untuk menjadi profesional. Sejalan dengan UUSPN No. 20 Tahun 2003 dalam pasal 10 yang tentang kompetensi pendidik yang meliputi:

\section{Kompetensi Pedagogik}

Kompetensi pedagogik merupakan kemampuan dalam pengelolaan pembelajaran peserta didik, menciptakan suasana dan pengalaman belajar bervariasi dalam pengelolaan peserta didik yang memenuhi kurikulum yang telah disiapkan yaitu :

a. Memiliki pemahaman wawasan atau landasan kependidikan

b. Memiliki pemahaman terhadap peserta didik

c. Mampu mengembangkan kurikulum atau silabus

d. Mampu menyusun rancangan pembelajaran

e. Melaksanakan pembelajaran yang mendidik dan dialogis

f. Melakukan evaluasi hasil belajar dengan prosedur yang benar

g. Mampu mengembangkan potensi peserta didik untuk mengaktualisasikan berbagai potensi yang dimilikinya

\section{Kompetensi Kepribadian}

Kompetensi kepribadian yang berakhlak mulia, arif dan berwibawa serta menjadi teladan badi peserta didiknya. Kepribadian merupakan salah satu unsur yang menentukan keakraban hubungan pendidik dan peserta didik yang tercermin dalam sikap dan perbuatannya dalam membina dan membimbing peserta didiknya. Pendidik harus memiliki dan melakukan perbuatan yang positif yang mencerminkan kepribadian:

a. Memiliki konsistensi dalam bertindak sesuai norma hukum, norma sosial, dan etika yang berlaku

b. Dewasa yang berarti memiliki kemandirian untuk bertindak sebagai pendidik dan memiliki etos kerja sebagai pendidik

c. Bijaksana dengan menunjukkan keterbukaan dalam berfikir dan bertindak

d. Berwibawa dengan berperilaku yang disegani sehingga berpengaruh positif terhadap peserta didik

e. Memiliki akhlak atau moral yang baik, bertindak sesuai norma religius, jujur, ikhlas, dan suka menolong.

\section{Kompetensi Sosial}

Kompetensi sosial pendidik merupakan kemampuan pendidik untuk memahami diriny sebagai bagian yang tidak terpisahkan dari masyarakat dan mampu mengembangkan tugas sebagi anggota masyarakat dan warga negara. Kompetensi sosial berkaitan dengan kemampuan pendidik berkomunikasi dan berinteraksi secara efektif dan efisien dengan peserta didik.

\section{Kompetensi Profesional}

Kompetensi profesional adalah kemampuan pendidik dalam menguasai materi pelajaran secara luas dan mendalam yang diperoleh melalui pendidikan profesi. Ada 4 pengetahuan dasar yang harus dimiliki seorang pendidik profesional, anatara lain: 
Volume 3 Nomor 2 Edisi Desember 2018

P-ISSN : 2541-3686

a. Pendidik harus mengenal setiap peserta didik yang dipercayakannya, unuk mengetahui sifat-sifatnya, kebutuhannya, pribadinya serta aspirasinya

b. Pendidik harus mmiliki kecakapan memberi bimbingan dalam bentuk intelektual dan psikologis

c. Pendidik harus memiliki dasar pengetahuan yang luas tentang tujuan pendidikan. Perkembangan anak senantiasa meningkat sesuai dengan zaman yang mengikutinya

d. Pendidik harus memiliki pengetahuan yang bulat dan baru mengenai ilmu yang diajarkannya. Dengan perkembangan ilmu pengetahuan dan teknologi, maka penmgetahuan-pengetahuan lama akan segera menjadi usang dan tidak relevan lagi dengan tuntutan zaman

e. Hasilnya peserta didik akan menjadi manusia masa depan yang handal, dapat menghadapi, memecahkan dan menyelesaikan berbagai persoalan yang muncul serta dapat menghadapi tantangan perkembangan zaman yang semakin berkembang.

Adapun petunjuk Al-Quran yang memberikan isyarat kepada kompetensi diatas adalah: surat al-Baqarah 164 dan 247, Al-Nisa' 162, Yusuf 22 dan 68, Al-Naml 15 dan 40, Al-Kahfi 65, Thahaa 114, Al-Anbiya 74 dan 79, Al-Qashash 14, Al-Ankabut 35 (menguasai ilmu dan materi yang diajarkan dan berpikir logis).surat Al-Baqarah 103 dan 283, Al-A'raaf 79 Dan 93, Al-Ra'du 21, Al-Syuura 59, Al-Ahqaaf 35, Al-Nisa' 63, Al-Zumar 53, Al-Ahzab 53, AlMaidah 54, Ali Imran 134, Maryam 51, Lukman 19, Al-Isra 37, Al-Anfal 47 (kompetensi social). surat Al-Baqarah 247, Al-Ahqaaf 9, Al-A'raf 31, Al-Saba 10 (menguasai ketrampilan, kesenian, berbadan sehat dan kuat), Al-Rahman 1, Lukman 19, Al-An'am 112 (menguasai kecakapan verbalistik).

\section{Simpulan}

Dalam pandangan Al-Quran surat Al-Isra': 84, sebagaimana pendapat para mufassir diatas, memberikan isyarat yang mengarah pada adanya petunjuk bahwa suatu perbuatan atau pekerjaan, apapun jenis profesi yang disandang, hendaknya dilakukan dengan profesional. Pernyataan ini diambilkan dari adanya pendapat mufasir yang memberikan penekanan terhadap makna kata kata 'ala syakilatihi, kata tersebut bermakna bentuk, tabiat, jalan, tujuan, niat, agama, kebiasaan, akhlak dan madzhab. Kesemuanya itu dapat dipahami dalam arti kondisi seseorang mampu melaksanakan pekerjaan yang dikehendakinya semaksimal mungkin. Dari sinilah yang dapat ditarik pemahaman bahwa Al-Quran memberikan isyarat pekerjaan itu harus dilakukan secara profesional. Demikian pula dengan profesi guru harus dilakukan secara profesional. 


\section{DAFTAR PUSTAKA}

Ahmad Tafsir, 2003, Ilmu Pendidikan dalam Perspektif Pendidikan Islam, Cet. VII; Bandung PT. Remaja Rosdakarya.

Al-Maraghi, 1946, Tafsir Al-Maraghi, Mesir: Al-Babi Al- Halabi.

Al-Mawardi, t.t, An-Nukat wa Al-Uyun, Beirut, Dar Al-Kutub Al-Ilmiyyah.

As-Suyuthi, 1974, Al-Itqan fi Ulum Al-Quran, Mesir, Al-Haiah Al-Mishriyyah.

At-Thabari, 2000, Jami' Al-Bayan fi Ta'wil Al-Quran, Muassasah Ar-Risalah.

Az-Zamakhsyari, 1470, Al-Kasysyaf, Beirut, Dar Al-Kitab Al-Arabi.

Depdikbud, 2005, Kamus Besar Bahasa Indonesia, Jakarta: Balai Pustaka.

Ibnu Katsir, 1999, Al-Quran Al-Azhim, Dar Thayuibah.

Ibnu Qutaibah, Gharib Al-Quran, tt.

Muhadjir, N. 2000, Ilmu Pendidikan dan Perubahan Sosial: Teori Pendidikan Pelaku Sosial Kreatif, Yogyakarta: Rake Sarasin.

Naquib al-Attas, 1997, Konsep Pendidikan dalam Islam: Suatu Rangka Pikir Pembinaan Filsafat Pendidikan Islam, Bandung: Mizan.

Nawawi Al-Bantani,1417, Marah Labid, Beirut: Dar Al-Kutub Al-Imiyyah.

Partanto, P. A., 1994,Kamus ilmiah populer, Surabaya: Arkola.

Purwanto, Y, 2007, Etika Profesi: Psikologi Profetik Perspektif Psikologi Islami, Bandung: Refika Aditama.

Sayyid Quthb, Fi Zhilal Al-Quran, Beirut, Dar As-Syuruq, 1412 H

Syafei,I. 1992, Konsep Guru Menurut Al-Ghazali, Pendekatan Filosofis Pedagogis, Yogyakarta: Duta Pustaka. 